\title{
PUBLICATIONS OF THE
}

\section{PHILADELPHIA ANTHROPOLOGICAL SOCIETY}

\author{
Volume I \\ Twenty-fifth Anniversary Studies
}





\title{
PUBLICATIONS OF THE \\ PHILADELPHIA ANTHROPOLOGICAL SOCIETY
}

\author{
Volume I \\ Twenty-fifth Anniversary Studies
}

Edited by

D. S. DAVIDSON

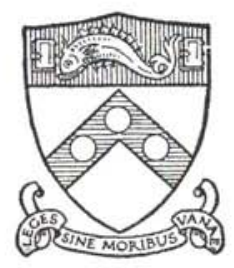

Philadelphia

UNIVERSITY OF PENNSYLVANIA PRESS

London: Humphrey Milford: Oxford University Press

1937 


\section{Copyright 1937}

UNIVERSTTY OF PENNSYLVANIA PRESS

Manufactured in the United States of America by the Lancaster Press, Inc., Lancaster, Pa. 